\title{
Structural Investigation of Steel Fiber Reinforced Concrete Subjected to Impact Loading
}

\author{
Anes Ebrahim Abo Horan ${ }^{1}$, Sumant Shinde ${ }^{2}$, Mrudula S. Kulkarni ${ }^{3}$ \\ ${ }^{1}$ Department of Structural Engineering Maharashtra Institute of Technology (MIT), Pune, India \\ ${ }^{2,3}$ Professor, Department of Structural Engineering Maharashtra Institute of Technology (MIT), Pune, India
}

\begin{abstract}
Normally concrete structures are designed for static loads. Sometime such structures are coming across the dynamic loads arising from military activities, terrorist activities. Therefore, this investigation will undertake to provide the needed information about the influence of various parameters on performance characteristics of steel fiber reinforced concrete and increased need to strengthen concrete structures. This study aims to investigate the impact resistance of fiber reinforced concrete (FRC), incorporated with steel fibers at various dosages. For this, a drop weight test was performed on the 28 days cured plain and fiber reinforced concrete specimens. End hook, Crimped and flat steel fiber of length $35 \mathrm{~mm}$ and an aspect ratio equal to 80, 50, 77.77, 46.66 were added to concrete in proportion $1.5 \%$ with water cement ratio of 0.40 . The experimental test results of steel reinforced fiber concrete are compared with plain concrete and conclusions are arrived.
\end{abstract}

Keywords: Steel fiber, reinforced concrete, impact loading, drop weight test, structural investigation

\section{Introduction}

Concrete is most widely used construction material in the world due to its ability to get cast in any form and shape. It also replaces old construction materials such as brick and stone masonry. The strength and durability of concrete can be changed by making appropriate changes in its ingredients like cementitious material, aggregate and water and by adding some special ingredients. Hence concrete is very well suitable for a wide range of applications.

The presence of micro cracks in the mortar-aggregate interface is responsible for the inherent weakness of plain concrete. The weakness can be removed by inclusion of fibers in the mixture. Different types of fibers, such as those used in traditional composite materials can be introduced into the concrete mixture to increase its toughness, or ability to resist crack growth. The fibers help to transfer loads at the internal micro cracks.

Such a concrete is called fiber-reinforced concrete (FRC) Concrete is characterized by brittle failure, the nearly complete loss of loading capacity, once failure is initiated.

\section{Research Methodology}

The experimental program consists of casting and testing of square steel fiber reinforcement concrete slab panels under drop weight impact test. The variables were the thickness of panels.

\subsection{Materials Used}

\subsubsection{Cement:}

Ordinary Portland cement of grade 53 conforming to IS: $12269-1987$

\subsubsection{Fine Aggregate (River sand):}

Locally available, clean, well dried and good graded natural river sand was used throughout the IS sieve $2.36 \mathrm{~mm}$.

\subsubsection{Course Aggregate}

Crushed blue granite aggregates passing through $10 \mathrm{~mm}$ sieve.

\subsubsection{Steel fiber}

Table 2.1: bekaert steel fiber

\begin{tabular}{|c|c|c|c|}
\hline Type of steel fiber & Diameter & Length & Aspect ratio \\
\hline End hook & 0.7 & 56 & 80 \\
\hline End hook & 0.7 & 35 & 50 \\
\hline
\end{tabular}

Table 2.2. Shaktiman steel fiber

\begin{tabular}{|c|c|c|c|}
\hline Type of steel fiber & Diameter & Length & Aspect ratio \\
\hline End hook & 0.45 & 35 & 77.77 \\
\hline End hook & 0.75 & 35 & 46.66 \\
\hline Cramped fiber & 0.45 & 35 & 77.77 \\
\hline Cramped fiber & 0.7 & 35 & 50 \\
\hline Flat fiber & & & 50 \\
\hline
\end{tabular}

\subsection{Experimental set up and testing procedure}

\subsubsection{Impact test:}

'Toughness' of a material is defined as the ability to absorb energy without fracture and it is generally determined by two methods:

1) By measuring deformation under an impact load and

2) By determining the energy required to cause complete failure of the specimen under an impact load. Several methods have been used for evaluating impact strength of materials such as:

3) (i)Weighted pendulum Charpy type impact test

4) Drop-weight test

5) Projectile impact test

6) Instrumented pendulum impact test.

Drop weight impact test is also known as "repeated impact test" and it is the simplest and widely used method.

Eimp $=$ E $p=$ N. g. h. m.

Where Eimp- Impact energy; in joule

$\mathrm{N}$ - Number of blows

$\mathrm{h}$ - Height of drop weight (m)

m - Drop weight $(\mathrm{kg})$

\section{Volume 5 Issue 6, June 2016}




\section{International Journal of Science and Research (IJSR) \\ ISSN (Online): 2319-7064}

Index Copernicus Value (2013): 6.14 | Impact Factor (2015): 6.391

$\mathrm{g}$ - Acceleration due to gravity $(9.81 \mathrm{~m} / \mathrm{s} 2)$

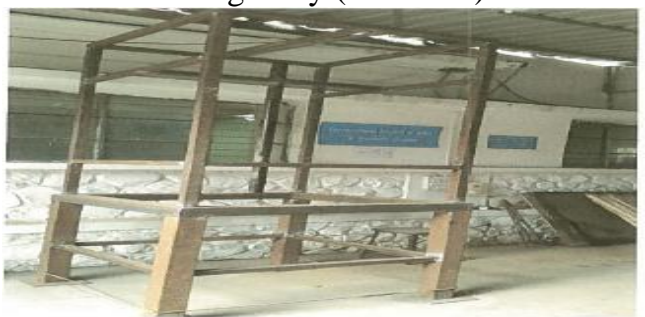

Figure 2.1: Impact test Apparatus

\section{Results}

\subsection{Drop Weight Impact Test Results}

Specimens calculation for finding energy absorption capacity of steel fiber panels at initial crack and ultimate failure $E_{\text {imp }}=$ N. g. h. m.

Where $\mathrm{E}_{\text {imp }}$ - Impact energy; in joule

$\mathrm{N}$ - Number of blows

$\mathrm{h}$ - height of drop weight (m)

$\mathrm{m}$ - Drop weight $(\mathrm{kg})$

$\mathrm{g}$ - acceleration due to gravity $(9.81 \mathrm{~m} / \mathrm{s} 2)$

Size of Panel $=250 \times 250 \times 50 \mathrm{~mm}$

First Crack- $4^{\text {th }}$ blow (4 Blows)

$\mathrm{I}_{\text {nitial }}=4 \times 9.81 \times 3.5 \times 1=137.34 \mathrm{~J}$

Ultimate failure- $10^{\text {th }}$ blow (10 Blows)

$\mathrm{E}_{\text {uitimate }}=10 \times 9.81 \times 3.5 \times 1=343.35 \mathrm{~J}$

\subsubsection{Energy absorption capacity of plain concrete panels}

Table 3.1: Test result for $50 \mathrm{~mm}$ thick panels without steel fiber

\begin{tabular}{|l|c|c|c|c|c|}
\hline Size of specimen & Specimen No & $\begin{array}{c}\text { No. of blow at } \\
\text { first crack }\end{array}$ & $\begin{array}{c}\text { No. of blow at } \\
\text { ultimate crack }\end{array}$ & $\begin{array}{c}\text { Impact energy at } \\
\text { first crack (J) }\end{array}$ & $\begin{array}{c}\text { Impact energy } \\
\text { ultimate crack (J) }\end{array}$ \\
\hline \multirow{3}{*}{$250 \times 250 \times 50$} & 1 & 4 & 10 & 137.34 & 343.35 \\
\cline { 2 - 6 } & 2 & 5 & 12 & 171.68 & 412.02 \\
\cline { 2 - 6 } & 3 & 6 & 11 & 206.01 & 377.68 \\
\hline & 4 & 5 & 10 & 171.68 & 343.35 \\
\hline
\end{tabular}

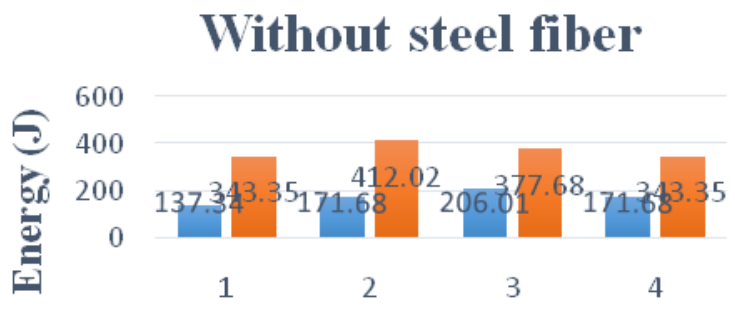

Specimen Number

- Initial U Ultimate

Figure 3.1: Initial and Final Energy Absorption Capacity of plain concrete panels

The number of blows required to cause the complete failure of specimen, which is used for calculating impact energy is shown in Table 4.1. Plain concrete (PC) resisted only eleventh blows prior to the failure of specimen and its corresponding impact energy was found to be $369.101 \mathrm{~J}$.

\subsubsection{Energy absorption capacity ofBeakart steel fiber} panels with aspect ratio 80

Table 3.2: Test result for End hook steel fiber aspect ratio 80 with $50 \mathrm{~mm}$ thick panels

\begin{tabular}{|c|c|c|c|c|c|}
\hline \multirow{2}{*}{ Size of specimen } & Specimen No & $\begin{array}{c}\text { No. of blow at first } \\
\text { crack }\end{array}$ & $\begin{array}{c}\text { No. of blow at } \\
\text { ultimate crack }\end{array}$ & $\begin{array}{c}\text { Impact energy at } \\
\text { first crack (J) }\end{array}$ & $\begin{array}{c}\text { Impact energy } \\
\text { ultimate crack (J) }\end{array}$ \\
\hline \multirow{3}{*}{$250 \times 250 \times 50$} & E80 - & 17 & 31 & 583.69 & 1064.38 \\
\cline { 2 - 6 } & E80 - & 15 & 32 & 515.02 & 1098.72 \\
\cline { 2 - 6 } & E80 - - & 16 & 30 & 549.36 & 1030.05 \\
\cline { 2 - 6 } & E80 - & 14 & 30 & 480.69 & 1030.05 \\
\hline
\end{tabular}

Volume 5 Issue 6, June 2016 www.ijsr.net 
International Journal of Science and Research (IJSR)

ISSN (Online): 2319-7064

Index Copernicus Value (2013): 6.14 | Impact Factor (2015): 6.391

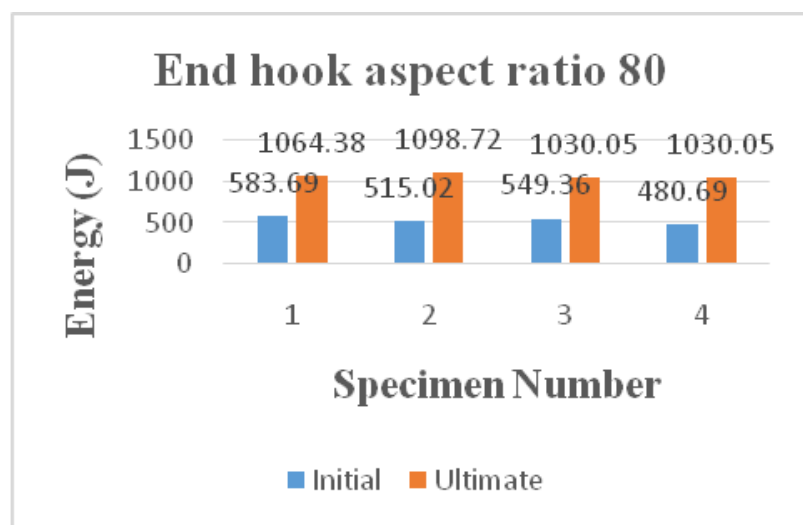

Figure 3.2: Initial and Final Energy Absorption Capacity of aspect ratio 80

\subsubsection{Energy absorption capacity of Beakart steel fiber panels with aspect ratio 50}

Table 3.3: Test result for End hook steel fiber aspect ratio 50 with $50 \mathrm{~mm}$ thick panels

\begin{tabular}{|c|c|c|c|c|c|}
\hline \multirow{2}{*}{ Size of specimen } & Specimen No & $\begin{array}{c}\text { No. of blow at first } \\
\text { crack }\end{array}$ & $\begin{array}{c}\text { No. of blow at } \\
\text { ultimate crack }\end{array}$ & $\begin{array}{c}\text { Impact energy at } \\
\text { first crack (J) }\end{array}$ & $\begin{array}{c}\text { Impact energy } \\
\text { ultimate crack (J) }\end{array}$ \\
\hline \multirow{3}{*}{$250 \times 250 \times 50$} & E50 - & 13 & 26 & 446.35 & 892.71 \\
\cline { 2 - 6 } & E50 - & 15 & 28 & 515.02 & 961.38 \\
\cline { 2 - 6 } & E50 - 3 & 14 & 25 & 480.69 & 858.37 \\
\cline { 2 - 6 }
\end{tabular}

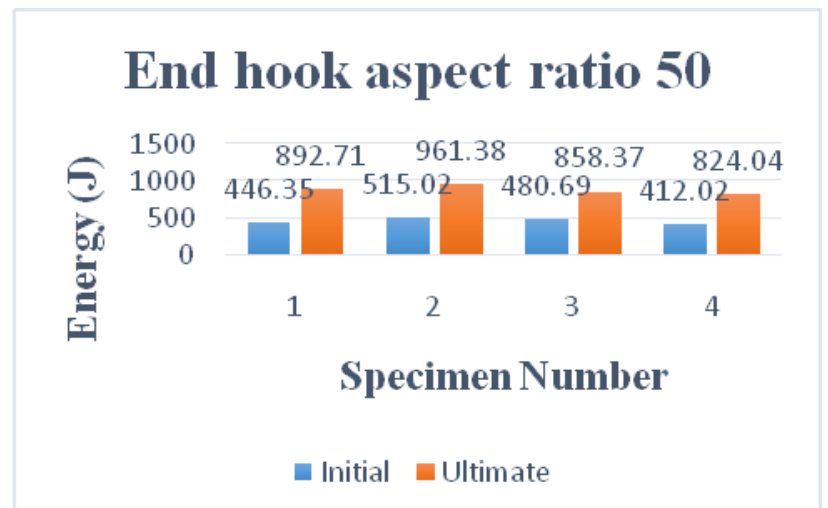

Figure 3.3: Initial and Final Energy Absorption Capacity of aspect ratio 50

3.1.4 Average value of energy absorption capacity ofBeakart steel fiber panels with aspect ratio 80,50 and without steel fiber:

Table 3.4: Average value of test result for $50 \mathrm{~mm}$ thick panels with aspect ratio 80,50 and without steel fiber

\begin{tabular}{|c|c|c|c|c|}
\hline Size of specimen & aspect ratio & Type of steel fiber & $\begin{array}{c}\text { Average initial energy at } \\
\text { absorption capacity (J) }\end{array}$ & $\begin{array}{c}\text { Average ultimate energy } \\
\text { at absorption capacity }(\mathrm{J})\end{array}$ \\
\hline \multirow{3}{*}{$250 \times 250 \times 50$} & Without steel fiber & & 171.67 & 369.101 \\
\cline { 2 - 5 } & 80 & End hook & 532.19 & 1055.8 \\
\cline { 2 - 5 } & 50 & End hook & 463.52 & 884.125 \\
\hline
\end{tabular}

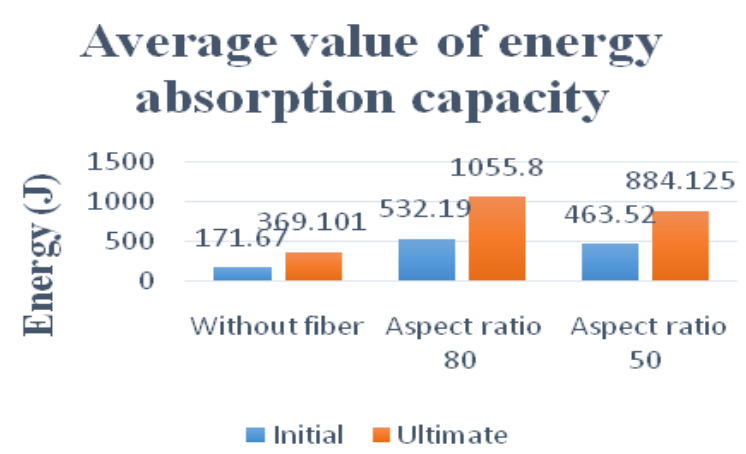

Figure 4.4: Average of Initial and Final Energy Absorption Capacity of aspect ratio 80, 50 and without steel fiber

Volume 5 Issue 6, June 2016 www.ijsr.net

Licensed Under Creative Commons Attribution CC BY 


\section{International Journal of Science and Research (IJSR) \\ ISSN (Online): 2319-7064}

Index Copernicus Value (2013): 6.14 | Impact Factor (2015): 6.391

For the Beakart steel fiber with end hook fibers (E 80, E 50) increase in the number of blows was 2.8 and 2.3 times as that of the plain concrete.

\subsubsection{Energy absorption capacity of Shaktiman steel fiber panels with aspect ratio 77.77}

Table 3.5: Test result for End hook steel fiber aspect ratio 77.77 with $50 \mathrm{~mm}$ thick panels

\begin{tabular}{|c|c|c|c|c|c|}
\hline \multirow{3}{*}{ Size of specimen } & Specimen No & $\begin{array}{c}\text { No. of blow at } \\
\text { first crack }\end{array}$ & $\begin{array}{c}\text { No. of blow at } \\
\text { ultimate crack }\end{array}$ & $\begin{array}{c}\text { Impact energy at } \\
\text { first crack (J) }\end{array}$ & $\begin{array}{c}\text { Impact energy } \\
\text { ultimate crack (J) }\end{array}$ \\
\hline \multirow{3}{*}{$250 \times 250 \times 50$} & E77.7 - & 20 & 38 & 686.7 & 1304.73 \\
\cline { 2 - 6 } & E77.7 - & 18 & 37 & 618.03 & 1270.39 \\
\cline { 2 - 6 } & E77.7 - 3 & 19 & 37 & 652.36 & 1270.39 \\
\cline { 2 - 6 } & E77.7 - & 20 & 39 & 686.7 & 1339.03 \\
\hline
\end{tabular}

4.1.6 Energy absorption capacity ofShaktimansteel fiber panels with aspect ratio 46.66

\section{End hook aspect ratio}

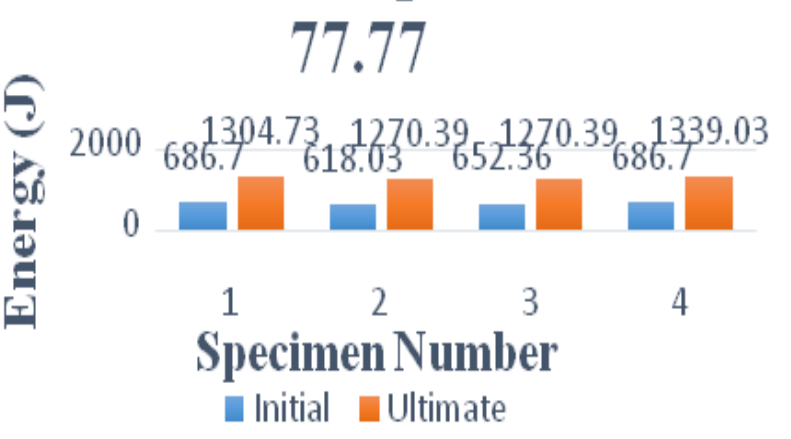

Figure 4.5: Initial and Final Energy Absorption Capacity of aspect ratio 77.77

Table 4.6: Test result for End hook steel fiber aspect ratio 46.66 with $50 \mathrm{~mm}$ thick panels

\begin{tabular}{|c|c|c|c|c|c|}
\hline Size of specimen & Specimen No & $\begin{array}{c}\text { No. of blow at first } \\
\text { crack }\end{array}$ & $\begin{array}{c}\text { No. of blow at } \\
\text { ultimate crack }\end{array}$ & $\begin{array}{c}\text { Impact energy at } \\
\text { first crack (J) }\end{array}$ & $\begin{array}{c}\text { Impact energy } \\
\text { ultimate crack (J) }\end{array}$ \\
\hline \multirow{3}{*}{$250 \times 250 \times 50$} & 17 & 36 & 583.69 & 1236.06 \\
\cline { 2 - 6 } & E46.6-1 & 16 & 35 & 549.36 & 1201.72 \\
\cline { 2 - 6 } & E46.6-2 & 19 & 37 & 652.36 & 1270.39 \\
\cline { 2 - 6 } & E46.6-3 & 18 & 36 & 618.03 & 1236.06 \\
\hline
\end{tabular}

\section{End hook aspect ratio 46.66}

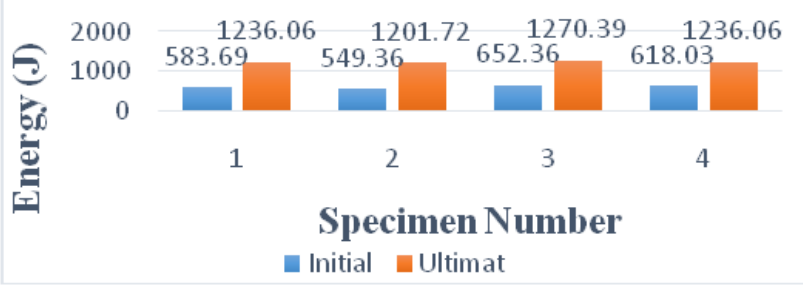

Figure 4.6: Initial and Final Energy Absorption Capacity of aspect ratio 46.66

3.1.7 Energy absorption capacity ofShaktiman steel fiber panels with aspect ratio 77.77

Table 3.7: Test result for Crimped steel fiber aspect ratio 77.77 with $50 \mathrm{~mm}$ thick panels

\begin{tabular}{|c|c|c|c|c|c|}
\hline Size of specimen & Specimen No & $\begin{array}{c}\text { No. of blow at first } \\
\text { crack }\end{array}$ & $\begin{array}{c}\text { No. of blow at } \\
\text { ultimate crack }\end{array}$ & $\begin{array}{c}\text { Impact energy at } \\
\text { first crack (J) }\end{array}$ & $\begin{array}{c}\text { Impact energy } \\
\text { ultimate crack (J) }\end{array}$ \\
\hline \multirow{3}{*}{$250 \times 250 \times 50$} & C77.7-1 & 15 & 36 & 515.02 & 1236.06 \\
\cline { 2 - 6 } & C77.7-2 & 17 & 39 & 583.69 & 1339.06 \\
\cline { 2 - 6 } & C77.7-3 & 16 & 36 & 549.36 & 1236.06 \\
\cline { 2 - 6 } & C77.7 - & 15 & 38 & 515.02 & 1304.73 \\
\hline
\end{tabular}

\section{Volume 5 Issue 6, June 2016 www.ijsr.net}




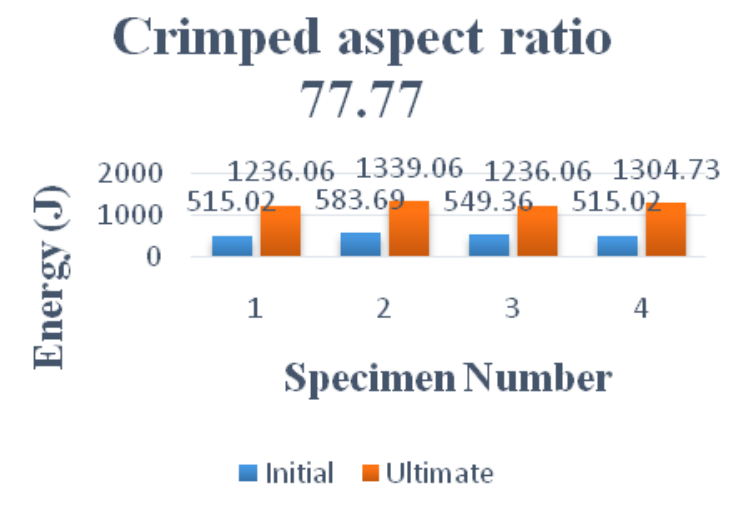

Figure 4.7: Initial and Final Energy Absorption Capacity of aspect ratio 77.77

4.1.8 Energy absorption capacity of shaktman steel fiber panels with aspect ratio 50:

Table 4.8 Test result for Crimped steel fiber aspect ratio 50 with $50 \mathrm{~mm}$ thick panels

\begin{tabular}{|c|c|c|c|c|c|}
\hline Size of specimen & Specimen No & $\begin{array}{c}\text { No. of blow at first } \\
\text { crack }\end{array}$ & $\begin{array}{c}\text { No. of blow at } \\
\text { ultimate crack }\end{array}$ & $\begin{array}{c}\text { Impact energy at } \\
\text { first crack (J) }\end{array}$ & $\begin{array}{c}\text { Impact energy } \\
\text { ultimate crack (J) }\end{array}$ \\
\hline \multirow{3}{*}{$250 \times 250 \times 50$} & C50 - & 12 & 27 & 412.02 & 927.04 \\
\cline { 2 - 6 } & C50 - & 14 & 29 & 480.69 & 955.71 \\
\cline { 2 - 6 } & C50-3 & 14 & 28 & 480.69 & 961.38 \\
\cline { 2 - 6 } & C50-4 & 15 & 30 & 515.02 & 1030.05 \\
\hline
\end{tabular}

\section{Crimped aspect ratio 50}

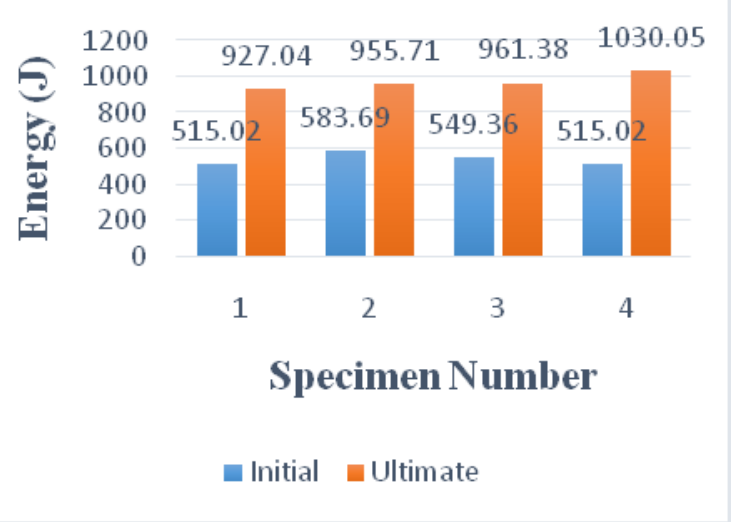

Figure 3.8: Initial and Final Energy Absorption Capacity of aspect ratio 50

3.1.9 Energy absorption capacity of Shaktiman steel fiber panels with aspect ratio

Table 3.9: Test result for Flat steel fiber aspect ratio 50 with $50 \mathrm{~mm}$ thick panels

\begin{tabular}{|c|c|c|c|c|c|}
\hline $\begin{array}{c}\text { Size of } \\
\text { specimen }\end{array}$ & $\begin{array}{l}\text { Specimen } \\
\text { No }\end{array}$ & $\begin{array}{c}\text { No. of blow at first } \\
\text { crack }\end{array}$ & $\begin{array}{l}\text { No. of blow at ultimate } \\
\text { crack }\end{array}$ & $\begin{array}{l}\text { Impact energy at first crack } \\
(\mathrm{J})\end{array}$ & $\begin{array}{l}\text { Impact energy ultimate crack } \\
(\mathrm{J})\end{array}$ \\
\hline \multirow{4}{*}{$250 \times 250 \times 50$} & F50 - 1 & 11 & 24 & 377.68 & 824.04 \\
\hline & F50 - 2 & 10 & 26 & 343.35 & 892.71 \\
\hline & F50 - 3 & 13 & 25 & 446.35 & 858.37 \\
\hline & F50 - 4 & 14 & 27 & 480.69 & 927.04 \\
\hline
\end{tabular}

\section{Volume 5 Issue 6, June 2016} www.ijsr.net 


\section{International Journal of Science and Research (IJSR) \\ ISSN (Online): 2319-7064}

Index Copernicus Value (2013): 6.14 | Impact Factor (2015): 6.391

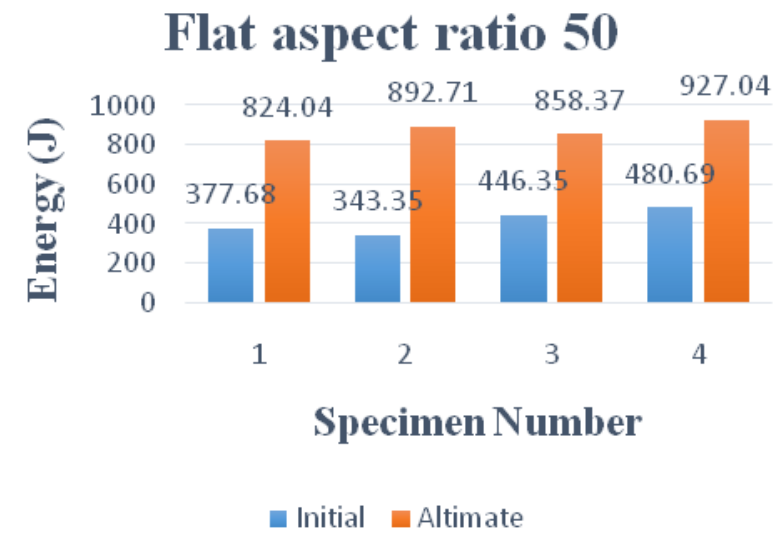

Figure 4.9: Initial and Final Energy

Absorption Capacity of aspect ratio 50

4.1.10 Average value of energy absorption capacity ofShaktiman steel fiber panels with aspect ratio 77.77 , 46.66, 77.77, 50, 50 and without steel fiber:

Table 3.10: Average value of test result for $50 \mathrm{~mm}$ thick panels with aspect ratio $77.77,50,46.66$ and without steel

\begin{tabular}{|c|c|c|c|c|}
\hline \multirow{4}{*}{$\begin{array}{c}\text { Size of } \\
\text { specimen }\end{array}$} & aspect ratio & $\begin{array}{c}\text { Type of } \\
\text { steel fiber }\end{array}$ & $\begin{array}{c}\text { Average } \\
\text { initial } \\
\text { energy at } \\
\text { absorption } \\
\text { capacity } \\
(\mathrm{J})\end{array}$ & $\begin{array}{c}\text { Average } \\
\text { ultimate } \\
\text { energy at } \\
\text { absorption } \\
\text { capacity } \\
(\mathrm{J})\end{array}$ \\
\hline \multirow{3}{*}{$\begin{array}{c}250 \times \\
250 \times 50\end{array}$} & $\begin{array}{c}\text { Without steel } \\
\text { fiber }\end{array}$ & & 171.67 & 369.101 \\
\cline { 2 - 5 } & 77.77 & End hook & 660.94 & 1296.14 \\
\cline { 2 - 5 } & 46.66 & End hook & 600.85 & 1236.06 \\
\cline { 2 - 5 } & 77.77 & Crimped & 527.89 & 1278.97 \\
\cline { 2 - 5 } & 50 & Crimped & 472.106 & 968.54 \\
\hline
\end{tabular}

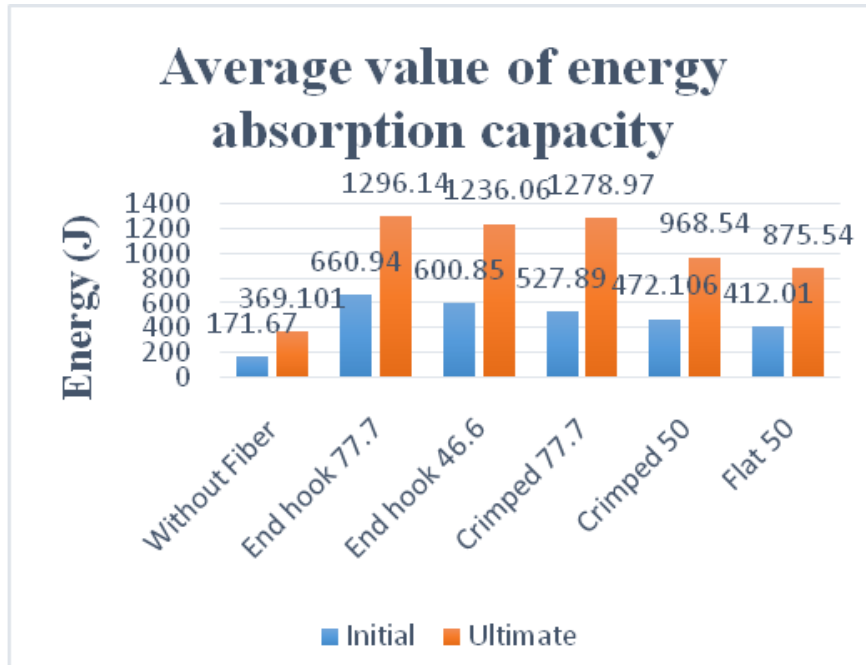

Figure 3.10: Average of Initial and Final Energy Absorption Capacity of aspect ratio 77.77, 50, 46.66 and without steel fiber

- For the Shaktiman steel fiber with end hook fibers (E 77.7, E 46.6) increase in the number of blows was 3.45 and 3.27 times as that of the plain concrete.
- The impact energy at failure was increased by $251 \%$ and $235 \%$ for end hook steel FRC (E 77.7-E 46.6) respectively.

- For the Shaktiman steel fiber with crimped fibers (C 77.7, C 50) increase in the number of blows was 3.3 and 2.63 times as that of the plain concrete.

- The impact energy at failure was increased by $246 \%$ and $162.4 \%$ for crimped steel FRC (C 77.7-C 50) respectively.

- For the Shaktiman steel fiber with flat fibers (F 50) increase in the number of blows was 2.3 times as that of the plain concrete.

- The impact energy at failure was increased by $137.2 \%$ for crimped steel FRC (F 50) respectively.

\subsection{Compressive Strength Test Results}

Table 3.11: Compressive strength

\begin{tabular}{|c|c|}
\hline Type of fiber & Compressive strength \\
\hline Plain concrete & 45.03 \\
\hline \multicolumn{2}{|c|}{ Beakart steel fiber } \\
\hline End hook 80 & 55,55 \\
\hline End hook 50 & 51,55 \\
\hline \multicolumn{2}{|c|}{ Shaktiman steel fiber } \\
\hline End hook 77,7 & 59,1 \\
\hline End hook 46,6 & 55,5 \\
\hline Crimped 77,7 & 57,18 \\
\hline Crimped 50 & 54,1 \\
\hline Flat 50 & 51,1 \\
\hline
\end{tabular}

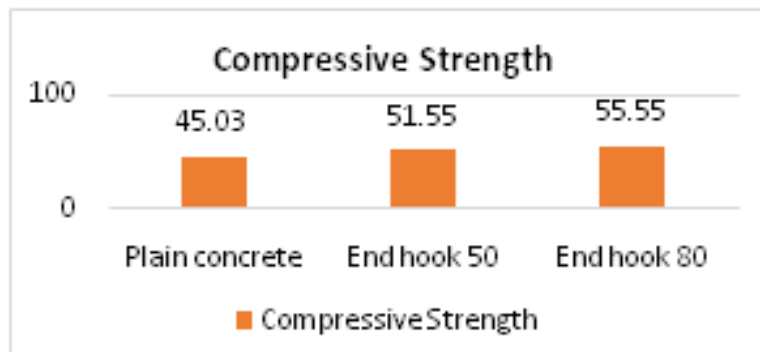

Figure 3.11: Compressive strength plain concrete - Beakart steel fiber

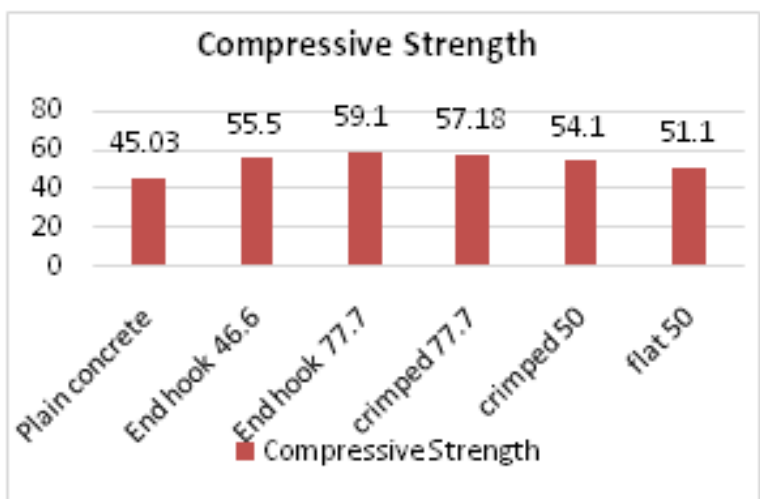

Figure 3.12: Compressive strength plain concrete Shaktiman steel fiber

The compressive strength of Beakart end hook steel FRC (E 80 - E 50) was increased by $23.37 \%$, and $14.47 \%$ respectively when compared to $\mathrm{PC}$.

The compressive strength of Shaktiman end hook steel FRC (E 77.7 - E 46.6) was increased by $31.24 \%$, and $23.25 \%$ respectively when compared to $\mathrm{PC}$

\section{Volume 5 Issue 6, June 2016 www.ijsr.net}




\section{International Journal of Science and Research (IJSR) \\ ISSN (Online): 2319-7064}

Index Copernicus Value (2013): 6.14 | Impact Factor (2015): 6.391

The compressive strength of Shaktiman crimped steel FRC (C 77.7 - C50) was increased by $26.98 \%$, and $20.14 \%$ respectively when compared to $\mathrm{PC}$

\section{Conclusions}

For the Beakart FRC with end hook fibers (E 80, E 50) increase in the number of blows as that of the plain concrete. For the Shaktiman FRC with end hook fibers (E 77.7, E 46.6, C 77.7, C 50 and F 50) increase in the number of blows as that of the plain concrete.

The impact energy at failure, increases in all the cases of end hook, crimped and flat Shaktiman FRC when compared to plain concrete and this increase in energy is slightly greater in case of end hook fiber when compared to crimped and flat fibers. Also, the impact energy at failure, increases in both the cases of end hook Shaktiman FRC and end hook Beakart FRC when compared to plain concrete and this increase in energy is slightly greater in case of end hook Shaktiman FRC when compared to end hook Beakart FRC.

\section{References}

[1] Li, V.; Yang, E.; Li, M. (28 January 2008), Field Demonstration of Durable Link Slabs for Joint less Bridge Decks Based on Strain-Hardening Cementitious Composites - Phase 3: Shrinkage Control (PDF), Michigan Department of Transportation

[2] http://www.core-construction-products.com/pdfs/ACI318-IBC-IRC-Evaluation-report-Helix-Steel-MicroRebar-Alternative-to-Steel-Rebar-Concretereinforcement-Vertical-Applications.pdf

[3] ACI 544.3R-93: Guide for Specifying, Proportioning, Mixing, Placing, and Finishing Steel Fiber Reinforced Concrete (PDF), American Concrete Institute, 1998

[4] Wang, Y.; Wu, HC.; Li, V. (November 2000). "Concrete Reinforcement with Recycled Fibers". Journal of Materials in Civil Engineering.

[5] Ochia, T.; Okubob, S.; Fukuib, K. "Development of recycled PET fiber and its application as concretereinforcing fiber". Cement and Concrete Composites 29 (6): 448-455. doi: 10.1016/j.cemconcomp.2007.02.002.

[6] Wietek, Bernhard (2008). Stahlfaserbeton. Vieweg+Teubner Verlag. ISBN 978-3-8348-0592-8.

[7] Richard W. S (1995). "History of Concrete" (PDF). The Aberdeen Group. Retrieved 25 April 2015.

[8] W. Morgan (1995). "Reinforced Concrete". The Elements of Structure. John F. Claydon (Civil Engineer). Retrieved 25 April 2015.

[9] Department of Civil Engineering (2015). "History of Concrete Building Construction". University of Memphis. Retrieved 25 April 2015.

[10] Mörsch, Emil (1909). Concrete-steel Construction: (Der Eisenbetonbau). The Engineering News Publishing Company. pp. 204-210.

[11] Collins, Peter (1920-1981). Concrete: The Vision of a New Architecture. McGill-Queen's University Press. pp. 58-60. ISBN 0-7735-2564-5.

[12] Mörsch, Emil (1909). Concrete-steel Construction: (Der Eisenbetonbau). The Engineering News Publishing Company. pp. 204-205.
[13] Mars, Roman. "Episode 81: Rebar and the Alvord Lake Bridge". 99\% Invisible. Retrieved 6 August 2014.

Volume 5 Issue 6, June 2016 www.ijsr.net 